\title{
The effect of a 1-year-long intensive Schroth therapy in patients with adolescent idiopathic scoliosis over 45 Cobb degrees who refused surgery in an outpatient clinic in Hungary, a case series
}

\author{
Judit Orban*, Krisztina Horvat \\ From 11th International Conference on Conservative Management of Spinal Deformities - SOSORT 2014 \\ Annual Meeting \\ Wiesbaden, Germany. 8-10 May 2014
}

\section{Background}

In curves more than $45 \mathrm{Cobb}$ degrees fusion is considered as basically the only possible treatment although studies about intensive Schroth intervention show that it may be effective in slowing curve progression of patients with Adolescent Idiophatic Scoliosis (AIS).

\begin{abstract}
Aim
The main purpose of this study was to evaluate the effect of an intensive, 1-year-long and individualized Schroth intervention on curve progression in patients with AIS more than $45 \mathrm{Cobb}$ degrees focused on the efficiency in terms of Cobb angle, axial trunk rotation (ATR) and objective body image.
\end{abstract}

\section{Design}

Prospective case series design

\section{Methods}

In this case series we included 7 female patients with AIS at the age of 13 with primary thoracic curve, wearing TLSO brace 23 hours/day, Risser: 2-3. The mean Cobb angle at the start of treatment was $47.3^{\circ} \pm 2.4^{\circ}$, while the mean ATR with Scoliometer was $14.3^{\circ} \pm 3.4^{\circ}$.

Patients received Schroth intervention for 12 months in an outpatient clinic. Schroth therapy was individual and personalized, 45 minutes weekly for each patient, combined with minimum 60 minutes of daily home

Scolinea Scoliosis Clinic, Budapest, Hungary
Schroth exercises 5 times per week. Outcomes were recorded at baseline, 6 and 12 months. Patients are currently in treatment.

\section{Results}

The Cobb angle improved $9.8^{\circ}$ in 4 patients, worsened $7^{\circ}$ in 1 patient, remained the same $2.5^{\circ}$, in 2 patients. The ATR measurements improved $5.3^{\circ}$ in 4 patients, remained the same in 3 patient. Objective body images gave a positive feedback to all patients.

\section{Conclusion}

In conclusion the results of this study confirm the effectiveness of an intensive 1-year-long, individual Schroth intervention for patients with AIS in curves more than $45^{\circ}$. At high risk of progression personalized Schroth intervention appears to be more effective in reducing the progression of scoliosis with additional bracing.

Published: 4 December 2014

\section{References}

1. Negrini S, Negrini F, Fusco C, Zaina F: Idiopathic scoliosis patients with curves more than 45 Cobb degrees refusing surgery can be effectively treated through bracing with curve improvements. Spine J 2011, 11(5):369-80, doi: 10.1016/j.spinee.2010.12.001. Epub 2011 Feb 2.

2. Negrini S, Zaina F, Romano M, Negrini A, Parzini S: Specific exercises reduce brace prescription in adolescent Idiopathic scoliosis: a prospective controlled cohort study With worst-case analysis. J Rehabil Med 2008, 40(6):451-5, doi: 10.2340/16501977-0195.

3. Weiß HR, Rigo M: Befundgerechte Physiotherapie bei der Skoliose. Pflaum Vlg GmbH 2006. 
doi:10.1186/1748-7161-9-S1-070

Cite this article as: Orban and Horvat: The effect of a 1-year-long intensive Schroth therapy in patients with adolescent idiopathic scoliosis over 45 Cobb degrees who refused surgery in an outpatient clinic in Hungary, a case series. Scoliosis 2014 9(Suppl 1):070.

Submit your next manuscript to BioMed Central and take full advantage of:

- Convenient online submission

- Thorough peer review

- No space constraints or color figure charges

- Immediate publication on acceptance

- Inclusion in PubMed, CAS, Scopus and Google Scholar

- Research which is freely available for redistribution

Submit your manuscript at www.biomedcentral.com/submit 